\title{
RINGTAIL IN NEW-BORN NORWAY RATS. A STUDY OF THE EFFECT OF ENVIRONMENTAL TEMPERATURE AND HUMIDITY ON INCIDENCE
}

\author{
BY MICHAEL TOTTON \\ London School of Hygiene and Tropical Medicine, Keppel Street, W.C. 1*
}

(With 2 Figures in the Text)

\section{INTRODUCTION}

Ringtail is a pathological condition in rats bred in the laboratory. It appears about 2 days after birth as a series of annular constrictions of the tail, which become more severe with increasing oedema between them. The skin on the hind legs and posterior dorsal region often desquamates. By the second week, the distal part of the tail is inflamed and haemorrhagic, and its attachment is dry and black. In such cases, the end of the tail falls off in a few days, leaving a stump which heals completely. Rats show no other signs of ill health or discomfort. They seldom if ever die as a result of the lesions; a few killed and autopsied have shown no visceral abnormalities.

Mild cases are easily missed as they clear up completely before weaning; in severe cases, outer hind toes or even a whole hind foot may show similar lesions leading to spontaneous amputation. The front limbs have never been found affected.

Ringtail has been found most frequent and most severe between November and May, and rare or absent in the summer.

In the litter history of a pair of rats, ringtail may occur once or several times in a season; a normal pair may produce ringtailed litters, or a ringtail pair normal litters; but all members of an affected litter show the condition, which therefore does not seem to be genetically determined.

Wooley \& Cole (1938) found a greater incidence among certain lines of rats or among the offspring of certain matings, but experience in this animal house does not confirm their claim.

Farris (1950), without discussing the cause, recommended raising the relative humidity of the breeding room to $50 \%$ or more with steam.

Njaa, Utne \& Braekkan (1957) in a note published while the present paper was in preparation also correlate incidence of ringtail with a low relative humidity.

Tail necrosis associated with fatty acid deficiency was first described by Burr \& Burr (1929). Graham \& Griffith (1931), Burr, Burr \& Brown (1931) and Hume \& Smith (1931) all discuss a similar condition. Evans \& Lepkovsky (1932) failed to observe the condition in rats on fat-free diets. Funk, Caspe \& Caspe (1931) describe a similar condition in rats housed in mesh-bottomed cages and fed various artificial

* Present address: The Wellcome Research Laboratories (Biological Division), Beckenham, Kent. 
diets, but do not consider what they observed to be the same condition as that described by Burr \& Burr (1929). McElroy \& Gross (1940) observed ringtail together with dermatosis of face, ears and paws in rats deficient in vitamin $B_{6}$. Burr (1942) finds tail necrosis unreliable as a sign of fatty acid deficiency, and relates scaly skin to humidity. He records a seasonal incidence. Kramar \& Levine (1953) did not encounter tail necrosis as a manifestation of fat or fatty acid deficiency.

It seems likely that the earlier observations on rats on deficient diets were complicated by true ringtail which, as is shown below, depends on humidity and temperature, and which has occurred in this animal house in animals fed throughout on MRC diet 4l, with no seasonal variation of diet. However, much of the work on deficiency diseases was done on weanling or mature rats, whereas, in this animal house, ringtail has been seen only in infant rats. The studies reported below, like those of Wooley \& Cole (1938), Farris (1950) and Njaa et al. (1957) refer only to infant rats.

\section{Infection}

No evidence of a specific causal infection was obtained. A specific search for ectromelia virus, by inoculation of mice and eggs, by inoculation of normal infant rats, by exchanging normal rat and mouse litters with ringtail rat litters, failed to reveal ectromelia. Burnet \& Lush (1936) state that rats can only with difficulty be infected with ectromelia, and only by way of the nasal mucosa.

\section{Experiment 1}

\section{Temperature and humidity}

At a time when the temperature in the animal house was $68-74^{\circ} \mathrm{F} .\left(20-23^{\circ} \mathrm{C}\right.$.) and relative humidity rarely above $50 \%$, a number of rats were allowed to breed in it, and others in a room in which temperature was kept at $75-80^{\circ} \mathrm{F}$. $\left(24-27^{\circ} \mathrm{C}\right.$.) with relative humidity $90-95 \%$. Pairs of rats were grouped in eight categoriesnamely, normal rats which had produced only normal litters, or only ringtail litters, or had been born of normal parents, or of ringtail parents; and ringtailed rats in four similar categories.

The pairs of rats were housed in wire-mesh cages resting above trays of sawdust. They were fed on MRC diet 41, with water ad libitum.

For each pair of rats in the humid room, a similar pair, often their littermates, was observed as a control under normal conditions in the animal house.

In the humid room, no ringtail occurred. There were twenty-five litters, two of which were killed by the mothers. At the same time, from November 1952 to July 1953, out of twenty litters in the control cages in the animal house, sixteen had ringtail and two were normal.

This experience leaves little doubt that an environmental factor was responsible for the occurrence of ringtail, the greatest environmental difference between the two sets of rats being that of humidity. 
Table 1. Distribution of ringtail between litters born in humid room and in animal house during same period

\begin{tabular}{ccccc}
\multicolumn{2}{c}{ Experimental room } & & $\overbrace{\text { No. of }}$ & Animal house \\
$\begin{array}{c}\text { Breeding pair } \\
\text { category }\end{array}$ & $\begin{array}{c}\text { No. of } \\
\text { litters }\end{array}$ & Condition & litters & Condition \\
l $a$ & 3 & Normal & 2 & Ringtailed \\
$b$ & 3 & Normal & 3 & Ringtailed \\
$2 a$ & 2 & Killed & 1 & Ringtailed \\
$b$ & 4 & Normal & 3 & Two ringtailed, one killed \\
$3 a$ & 3 & Normal & 2 & One ringtailed, one doubtful \\
$b$ & 2 & Normal & 4 & Ringtailed \\
$4 a$ & 1 & Normal & 2 & One ringtailed, one doubtful \\
$b$ & 4 & Normal & 3 & Two ringtailed, one killed \\
2nd generation & & & & \\
$3 a^{\prime}$ & 2 & Normal & & - \\
$4 b^{\prime}$ & 1 & Normal & & - \\
Ringtailed & 0 & - & 16 & - \\
Normal & 23 & - & $2(?)$ & - \\
Killed & 2 & - & 20 & - \\
Total & 25 & - & &
\end{tabular}

Key. 1, normal rats : $a$, producing only normal litters; $b$, producing some ringtailed litters. 2 , ringtailed rats: $a$, producing only normal litters; $b$, producing some ringtailed litters. 3, normal rats: $a$, born of normal parents; $b$, born of ringtailed parents. 4 , ringtailed rats: $a$, born of normal parents; $b$, born of ringtailed parents.

\section{Experiment 2}

In the normal animal house rooms, between September 1953 and April 1955, a comparison was made between the incidence of ringtail in rats housed in cages constructed entirely of wire mesh, raised 6-8 in. above the dropping trays, and in cages resting directly on the sawdust and provided with a strip of metal $1 \frac{1}{2}$ in. deep around the lower part of the sides. The two kinds of cage are designated 'raised' and 'contact'.

The occupant of each cage was a female rat previously mated in another cage and known to be pregnant. The females were marked so that they could be returned to their own cages after mating. An initial supply of fine wood wool was placed in each cage and not supplemented. Litters were recorded as 'normal', 'severe ringtail' or 'mild ringtail'. The litter was treated as a unit because all members of a litter were always affected alike.

Two rooms were used, alike in all respects save that one faced east and the other west. Since no difference in result was observed between the two rooms, the results for the two of them are treated together.

Table 2 shows clearly that the incidence of severe ringtail was much greater in the 'raised' cages than in the 'contact' cages. Mild ringtail occurred in both, but was definitely more common in the 'raised' cages. The seasonal fluctuation of ringtail was most marked with respect to the severe condition. 
Table 2. The distribution of ringtailed litters in the animal house between September 1953 and April 1955

$\begin{array}{lcrcc} & \begin{array}{c}\text { Total } \\ \text { litters }\end{array} & \begin{array}{c}\text { Severe } \\ \text { R.T.* }\end{array} & \begin{array}{c}\text { Mild } \\ \text { R.T.* }\end{array} & \text { Normal } \\ \begin{array}{l}\text { May-October both rooms } \\ \text { 'Raised' cages }\end{array} & 81 & 16 & 57 & 8 \\ \text { 'Contact' cages } & 80 & 0 & 33 & 47 \\ \text { November-April both rooms } & & & & \\ \text { 'Raised' cages } & 92 & 50 & 41 & 1 \\ \text { 'Contact' cages } & 96 & 4 & 62 & 30 \\ & \text { * Ringtailed. } & & & \end{array}$

Litters in which lesions, including amputation, were seen at weaning were classed as severe; if the litter record showed that earlier lesions had healed, they were classed as mild. A $\chi^{2}$-test of the association between season and incidence of ringtail showed that, where severe and mild lesions were listed separately, the probability of the association being due to chance was less than $1 \%$. Where the cases were listed together, the probability was less than $0.1 \%$.

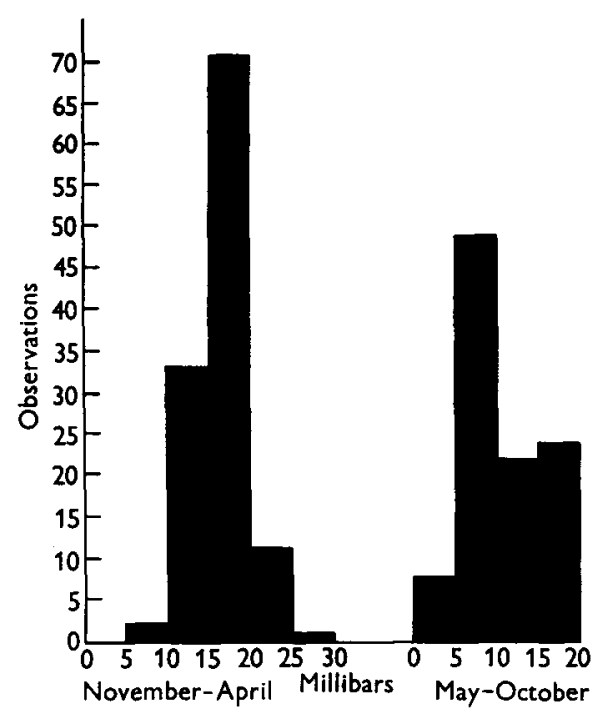

Fig. 1

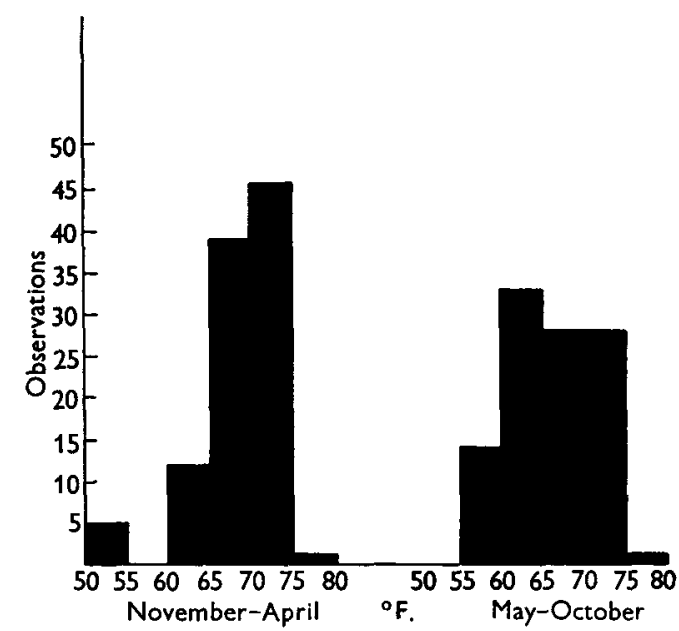

Fig. 2

Fig. 1. Room 4; saturation deficits in millibars, recorded by whirling hygrometer.

Fig. 2. Room 4; minimum temperatures, rocorded on commencing daily routine.

The bedding provided in each cage was almost always lost through the floor of the 'raised' cage within a few days of birth, while the greater part remained in the 'contact' cages throughout, and was kept together as a functional nest. This fact is considered significant, as the loss of the nest necessarily exposes the young to the general environment at an early age. In the 'raised' cages, air movement through the cage must have been greater than in the 'contact' cages.

In order to show the ranges of temperature and humidity in the animal house during this experiment, daily readings of both have been arranged in frequency groups and presented as histograms in Figs. 1 and 2. Temperatures are minimum temperatures, recorded each morning after $16 \mathrm{hr}$. without disturbance of the room. 
Humidity is expressed in millibars of saturation deficiency obtained from whirling hygrometer readings, as showing best the drying power of the atmosphere (Buxton, 1932).

In the May-October period, the most frequent level of saturation deficiency was $5-9 \mathrm{mb} .(3 \cdot 75-6 \cdot 75 \mathrm{~mm}$. $\mathrm{Hg})$, while in the November-April period it was $15-19 \mathrm{mb}$. $(11.25-14.25 \mathrm{~mm}$. $\mathrm{Hg})$. This represents a considerable difference in the dryness of the atmosphere. There was little difference between minimum temperatures in the two seasons. In the November-April period, the minimum temperature varied less, indicating more even temperatures, and during the May-October period, readings in the lower range $\left(55-64^{\circ} \mathrm{F}\right.$. or $13-18^{\circ} \mathrm{C}$.) were more frequent than in the winter season. In general, then, during the winter the atmosphere in the animal house remained dry and warm, while in the summer it varied more, and was on the whole cooler and relatively damp.

\section{Experiment 3}

In an attempt to study the effects of temperature and humidity separately, a controlled-environment chamber was made from an old refrigerator. In this, two rat cages rested on a wire shelf. Below the shelf was a tray, containing either fused calcium chloride or sawdust. Also on the floor of the chamber was the heat source, a $60 \mathrm{~W}$. electric light bulb, enclosed in a blackened metal hood through which the incoming air passed. The bulb was in circuit with a Sunvic bimetallic thermostat in the chamber. Incoming air was dried by pumping it in over concentrated sulphuric acid followed by soda-lime.

In hot weather, the incoming air also passed through a double metal coil placed in a refrigerator running at $10^{\circ} \mathrm{F}$. Icing-up of the cooling coils was prevented when necessary by drying the air before it entered them, and if necessary rehumidifying it by passing the cooled air through bottles of water.

By manipulation of the various components of the apparatus, most requisite combinations of temperature and humidity could be maintained, except that at temperatures of $65^{\circ} \mathrm{F}$. or lower it was not possible to obtain a saturation deficit of more than $15 \mathrm{mb}$.

Table 3 shows the incidence of ringtail in seventy-four litters studied in the controlled-environment chamber.

Table 3. The incidence of ringtail among litters reared from birth in the controlled temperature and humidity chamber

\begin{tabular}{crlcll} 
Dry bulb & $\begin{array}{c}\text { Saturation } \\
\text { deficit } \\
(\mathrm{mb})\end{array}$ & \multicolumn{2}{c}{ Litters } & & \\
$\left({ }^{\circ}\right.$ F.) & R.T. & Normal & Others & Total \\
90 & $38 \cdot 2$ & 10 (mild) & 0 & 2 eaten & 12 \\
90 & $5 \cdot 7$ & 0 & 8 & 1 eaten & 9 \\
80 & $26 \cdot 2$ & 8 (severe) & 0 & 2 doubtful & 10 \\
80 & $1 \cdot 6$ & 0 & 9 & 1 eaten & 10 \\
75 & $22 \cdot 7$ & 8 (mild) & 1 & - & 9 \\
75 & $2 \cdot 9$ & 0 & 9 & - & 9 \\
65 & $15 \cdot 0$ & 8 (severe) & 0 & - & 8 \\
65 & $4 \cdot 6$ & 0 & 0 & 7 moribund & 7
\end{tabular}


Ringtail occurred at all temperatures from 65 up to $90^{\circ} \mathrm{F}$. but only when the saturation deficit was high: it was not observed at low saturation deficiency at any temperature.

Temperature may have affected the severity of ringtail, but the association is not clear for although at $90^{\circ} \mathrm{F}$., the disease was mild, as it was at $75^{\circ} \mathrm{F}$., at the comparatively high temperature of $80^{\circ} \mathrm{F}$. it was severe.

At $65^{\circ} \mathrm{F}$., the lower limit of endurance of infant rats seems to have been reached, for even at high humidity, when they did not get ringtail, all seven litters died, with cyanosis, periodic paroxysmal extension of all limbs, and, judging by the lack of visible milk in the stomach, inability to suckle. Subdermal haemorrhages in the tail, usually pronounced at the tip, were visible to the naked eye, together with intense erythema of the hind feet and sometimes of the hind legs. These lesions were quite different in appearance from those of ringtail, but their further pathology was not investigated. All seven litters at $65^{\circ} \mathrm{F}$. and low saturation deficit were similarly affected; at higher temperatures, the same condition was not seen.

\section{DISCUSSION}

Rats are liable to develop ringtail if exposed during the first 2-3 days of post-natal life to an atmosphere with a saturation deficit of more than about $10 \mathrm{mb}$. $(7.5 \mathrm{~mm} . \mathrm{Hg})$. Atmospheric temperature is of secondary significance, if any, in the causation of ringtail.

In natural conditions, or in cages if they are satisfactory, infant rats pass their first 2-3 weeks in an environment which varies little in temperature and humidity, the latter being near saturation, because the nest, made of such hygroscopic material as vegetable fibres, hair, paper, or rag, protects them from air currents.

Kinder (1927) has shown that the structure of nests built by the Norway rat differ according to the temperature and humidity prevailing when they are built; a mechanism which presumably tends to regulate the environment of the infant rat.

Infant rats and mice cannot regulate their body temperature physiologically (Hill, 1947; Ware, Hill \& Schultz, 1947; Buchanan \& Hill, 1947) and lose heat rapidly in a cool environment. While in bodily contact with the mother in the nest, the young are maintained at or near her body temperature for most of the day and night.

In the 'raised' kind of cage described, in which proper nest building usually does not happen, the young are from the beginning exposed to chronic cooling by loss of heat from evaporation, by convection due to air movement and by conduction through the metal floor of the cage. Inquiry from twenty other animal houses revealed that the seven which had noted ringtail among their rats were the only ones using mesh-floored cages with a space beneath the floor (see Table 4). The correlation between ringtail and this kind of cage is clear.

From the standpoint of animal husbandry, the sanitary advantages of wiremeshed floors are outweighed by the physiological disadvantage unless the temperature and humidity can be kept at satisfactory levels either with adequate nesting facilities or by air conditioning. 
Table 4. Summary of essential facts obtained from the answers to a questionnaire on ringtail sent to twenty animal houses

$\begin{array}{lcccc} & \text { A and B } & \text { A only } & \text { C } & \text { Total } \\ \text { Ringtail observed } & 7 & 0 & 0 & 7 \\ \text { No ringtail observed } & 5 * & 2 & 6 & 13 \\ & * \text { One had nest box. } & \end{array}$

Animal houses where cages with mesh floors of any kind are used are symbolized by the letter A, those where the mesh floor has a space beneath it by the letter B. Where solid floors are used, the letter $\mathrm{C}$ is used in the table.

\section{SUMMARY}

Ringtail in infant rats is shown to depend on humidity over a wide temperature range. It is not due to infection or diet, but probably to chronic cooling by evaporation, convection and conduction.

Rats should either be bred in cages with solid floors, or else be given environmental conditions resembling those in the natural nest, which keep the young at a low saturation deficit during the early post-natal period.

I am glad to express my thanks to M. Potter, Senior Animal Technician, for his invaluable aid in keeping the records of the experimental programmes, and to G. Dimmock for his help in building and maintaining apparatus. I am also grateful to the University of London for the loan of a Cambridge portable potentiometer.

\section{REFERENCES}

Buchanan, A. R. \& Hinl, R. M. (1947). Proc. Soc. exp. Biol., N.Y., 65, 602.

Burnet, E. M. \& Lush, D. (1936). J. Path. Bact. 32, 469.

Burr, G. O. (1942). Fed. Proc. 1, 224.

Burr, G. O. \& BurR, M. M. (1929). J. biol. Chem. 82, 345.

Burr, G. O., Burr, M. M. \& Brown, W. R. (1931). Proc. Soc. exp. Biol., N.Y., 28, 905.

Buxton, P. A. (1932). Indian J. med. Res. 20, 1.

Evans, H. M. \& Lepkovsky, S. (1932). J. biol. Chem. 96, 143.

FArris, E. J. (1950). The Care and Breeding of Laboratory Animals. New York: Wiley. London: Chapman and Hall.

Funk, C., Caspe, S. \& Caspe, H. (1931). Proc. Soc. exp. Biol., N.Y., 28, 816.

Graham, C. E. \& Griffith, W. H. (1931). Proc. Soc. exp. Biol., N.Y., 28, 756.

HrLl, R. M. (1947). Amer. J. Physiol. 149, 650.

Huмe, Е. М. \& Sмгтн, H. Н. (1931). Biochem. J. 25, 300.

KINDER, E. F. (1927). J. exp. Zool. 47, 117.

Kramar, J. \& Levine, V. E. (1953). J. Nutr. 50, 149.

McElrox, L. W. \& Gross, H. (1940). Proc. Soc. exp. Biol., N.Y., 45, 717.

NJaA, Lieff Riein, Utne, Finn \& Brakkkan, O. R. (1957). Nature, Lond., 180, 290.

W are, A. G., Hill, R. M. \& Schultz, F. H. (1947). Amer. J. Physiol. 149, 657.

Wooley, G. W. \& Cole, L. J. (1938). J. Hered. 29, 123.

(MS. received for publication 4. x. 57) 